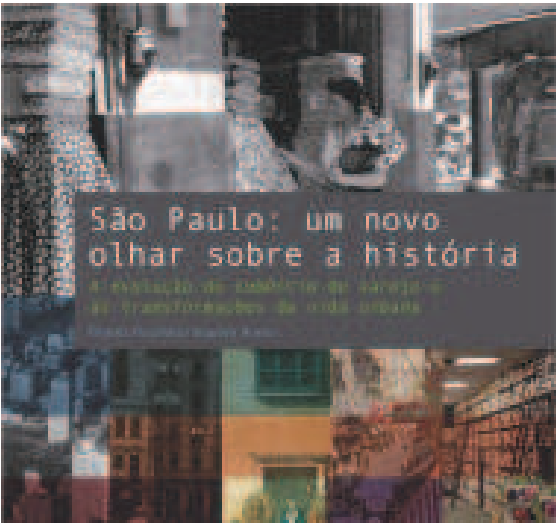

São Paulo: um novo

OLHAR SOBRE A HISTÓRIA.

A EVOLUÇÃO DO

COMÉRCIO DE VAREJO E AS

TRANSFORMAÇÕES DA VIDA

URBANA

BEATRiz Piccolotto Siqueira Bueno. São Paulo:Via das Artes, 2OI2. I44 P.PrESS, 2OII

Heloisa Barbuy

\title{
O Comércio de são paulo: eixo de Pesquisa sobre
} A CIDADE

Em São Paulo: um novo olhar sobre a História. A evolução do comércio de varejo e as transformações da vida urbana, Beatriz Piccolotto Siqueira Bueno nos propõe um trajeto para ver São Paulo, como se andássemos por suas principais ruas comerciais, integrando a vida da cidade, olhando as lojas com suas ofertas de coisas, muitas coisas, que bem podemos nos imaginar comprando ou usando. O novo olhar, indicado no título, refere-se, portanto, à compreensão de que a vivência cotidiana e urbana pode e deve ser entendida como história, o que, para muitos, pode estar talvez distante de uma visão mais restrita a respeito do que é a história e também o documento histórico. Aqui, imagens de cenas banais que registra a cidade de todos os dias, ou anúncios concebidos para atrair o consumidor anônimo e que, por isso mesmo, o representam, são documentos plenos de informações, sobre a cidade e a vida urbana.

Trata-se, segundo a autora, de um "livro panorâmico". De fato, recupera percursos de compras rotineiramente realizados por milhares de pessoas, em sucessivos períodos, e que acabaram por se inscrever, nas memórias afetivas e nos imaginários coletivos, como lugares urbanos bem identificados. O panorama que nos é trazido nesta obra cobre mais de duzentos anos de história. Não por acaso, inicia-se em 1809, ano que, por suas próprias pesquisas anteriores, a autora descobriu ser um marco na história da cidade, pois foi então, ainda no período colonial, que se introduziu o primeiro imposto predial e, com ele, a primeira numeração das casas. É assim, com uma interpretação elaborada de informações que podem parecer miúdas ou meramente administrativas, que se tem chegado a resultados inovadores e aprofundados, em pesquisas sobre as realidades cotidianas da cidade de São Paulo, ao longo de sua história. 
O trajeto proposto é estruturado em cinco períodos, que nos levam como que a percorrer, primeiro, as ruas de terra batida (1809-1862), que, mais tarde, recebem as pedras "pé de moleque", passeios laterais e iluminação a gás em lampiões de ferro, os leitos, em seguida, substituídos por paralelepípedos, nos quais seriam instalados os trilhos de bondes (1862-1939). Encontramos, depois, as calçadas largas da "Cidade Nova", na Rua Barão de Itapetininga e adjacências, já concebidas para os deslocamentos de pedestres na cidade povoada de casas comerciais (1939-1956), para caminhar, na sequência, pela Rua Augusta, em algum momento asfaltada, até os shopping centers (19562000). No final, a autora analisa as tendências atuais do comércio, da chic Rua Oscar Freire à popular 25 de Março (que convivem, firmes, com os shoppings centers), sem esquecer as novas práticas de consumo a distância (2000-2012).

A obra "não se pretende acadêmica", como alerta a autora, mas nem por isso deixa de recorrer e mesmo sublinhar, em alguns casos, uma viva produção acadêmica, que vem se encorpando, nos últimos anos, sobre o tema do comércio. Conquanto antes já houvesse obras importantes, impressiona a quantidade e qualidade de trabalhos acadêmicos que vêm tendo o comércio como eixo, desde o início dos anos 2000, em especial sobre a Cidade de São Paulo. Todos se completam e se enriquecem, em suas diferentes abordagens, perspectivas, recortes temporais e espaciais escolhidos. Beatriz Bueno sabe agregar e valorizar tudo isso, indo também diretamente às fontes, nos casos em que ninguém se aventurou ainda. Pode-se dizer que é conhecimento acadêmico para leitura de todos, "gênero" este que se faz cada vez mais necessário, pois a universidade precisa se aproximar da sociedade, que tem avidez por compreensão de realidades históricas.

Também a sequência das muitas imagens, que nutrem, visualmente, os caminhos que somos levados a percorrer pelas ruas paulistanas, é muito rica, e mesmo imagens bem conhecidas, ao menos dos estudiosos de São Paulo, como a Vista da cidade - Palácio da Sola, de Edmund Pink, de 1823, ganha outra leitura, por estar inserida nesta obra, que destaca a loja em que se veem couros pendurados (as solas), pilões, vassouras, peneiras e barris, à vista do transeunte, senhor à porta, provavelmente o proprietário. Um projeto gráfico leve e arejado, com distribuição que sugere movimento, cores variadas e suaves, aliado à excelente qualidade das reproduções, deixa-nos meio alegres e soltos, para mergulhar na vida urbana, especialmente diurna, a que nos remetem os anúncios, fotos, mapas e listas. São imagens variadas, que nos colocam diante de fachadas e interiores de lojas, ou no lugar do leitor de um jornal ou revista de outros tempos, que seria atraído por anúncios charmosos. Merecem destaque as espacializações que Beatriz Bueno realizou para cada período, com a localização das lojas de referência.

É um livro para experimentar. Uma escrita clara e bem referenciada nos situa, de forma segura, nos diferentes contextos abordados. Virando as páginas, vamos percebendo, ao longo do tempo, toldos listados com inscrições, comércio popular próximo a mercados, o famoso Salão de Chá da Casa Mappin, mulher absorta diante de uma vitrine, homens de terno e gravata tomando café em balcão, guarda-chuvas abertos e roupas onduladas pelo vento, na Avenida São João, e, ainda hoje, os chapéus espalhados no interior da Chapelaria Plas, na 
Rua Augusta, e portentosos shoppings centers (57 foram identificados por Beatriz Bueno, o primeiro deles inaugurado em 1966). O interior da Casa da Bóia e as vitrines da El Sombrero, típicas de uma estética do centro da cidade, honram a longa duração de uns poucos estabelecimentos comerciais já centenários. São algumas das muitas imagens que ficam passeando por nossa cabeça, mesmo depois que fechamos o livro.

\section{Heloisa Barbuy}

É autora de A Cidade-Exposição: comércio e cosmopolitismo em São Paulo, 18601914 (EDUSP, 2006), originalmente tese de doutoramento orientada pelo professor Benedito Lima de Toledo e defendida na FAUUSP, em 2001. É professora e curadora do Museu Paulista/USP e professora do Programa de Pós-Graduação em História Social da FFLCH/USP e do Programa de Pós-Graduação Interunidades em Museologia/USP.

Universidade de São Paulo, Museu Paulista, Divisão Científica.

Caixa Postal 42.403, Ipiranga

04218-970 - São Paulo, SP

(11) 2065.8036

hbarbuy@usp.br 